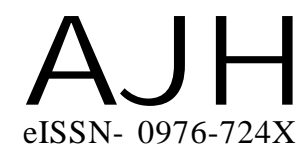

Received : 19.10 .2015

Revised : 09.11.2015

Accepted : 21.11.2015

RESEARCH PAPER

THEASIAN JOURNAL OF HORTICULTURE

Volume 10 | Issue 2 | December, 2015 | 267-271

Visit us -www.researchjournal.co.in

DOI : $10.15740 / \mathrm{HAS} / \mathrm{TAJH} / 10.2 / 267-271$

\title{
Effect of potassium and zinc deficiencies on growth parameters of gerbera under polyhouse condition
}

\section{H.B. KALBHOR ${ }^{1}$, K. MURALI MOHAN ${ }^{1}$ AND A.V. PATIL}

ABSTRACT : The results of the experiment revealed that $\mathrm{K}$ and $\mathrm{Zn}$ deficient treatments showed significantly inferior results in respect to growth parameters viz., number of suckers per plant, number of leaves per plant, plant height and plant spread. The $\mathrm{K}$ and $\mathrm{Zn}$ deficient treatments showed significantly inferior results in respect to quality parameters viz., height of flower stalk, flower diameter, green and dry weight of individual flower, vase life of flower, number of flower per plant and more number of days required for flower maturity over all nutrients application treatments. The significant reduction in yield of gerbera, green and dry matter production per plant, nutrient content and nutrient uptake observed due to the $\mathrm{K}$ and $\mathrm{Zn}$ deficient treatment. The K deficient treatments showed marginal necrosis of leaves and flowers became pale, which are the typical symptoms. The $\mathrm{Zn}$ deficient treatments showed formation of smaller sized thicker leaves which caused rosette formation and interveinal chlorosis of leaves with green spots at somewhere which are typical symptoms.

KEY WORDS : Potassium, Zinc, Deficiency, Growth, Gerbera, Polyhouse

HOW TO CITE THIS ARTICLE : Kalbhor, H.B., Mohan, K. Murali and Patil, A.V. (2015). Effect of potassium and zinc deficiencies on growth parameters of gerbera under polyhouse condition. Asian $J$. Hort., 10(2) : 267-271. 